\title{
CULTURAL TRANSFER AND BILINGUALISM IN THE DOCUMENTARY 389 MILES: LIVING THE BORDER BY LUIS CARLOS DAVIS
}

\author{
An Van Hecke 1 \\ ${ }^{1}$ Katholieke Universiteit Leuven, Leuven, Flandres, Belgium
}

\begin{abstract}
The use of multiple languages in movies often involves negative stereotyping of characters belonging to a minority represented in those films. This is the case with some Hollywood films in which Spanish is associated with exotic or dangerous characters, confirming persistently the dominant position of the English language. In the documentary 389 Miles: Living the Border (2009) the linguistic and cultural impact of migration is seen from quite a different perspective. Whereas most of the documentaries dealing with the Mexican-American border are predominantly in English, possibly with Spanish subtitles, or mainly in Spanish with English subtitles, in 389 Miles both languages are used equally. The narrator tells the story in English, but he uses both languages in the interviews. There are also a few characters who switch from English to Spanish. The aim of this article is threefold: in a first instance, it seeks to examine the documentary with the use of some basic concepts of Polysystem Theory. The second objective is to explore language diversity. In a third instance, this article aims to shed more light on two powerful Mexican symbols: viz. the Virgin of Guadalupe and the wrestler mask. The final objective is to find out how bilingualism in documentaries changes our perception on other cultures, border crossing and migration.
\end{abstract}

Key Words: Multilingualism; Polysystem Theory; Documentary; Cultural Transfer 


\title{
A TRANSFERÊNCIA CULTURAL E O BILINGUISMO NO DOCUMENTÁRIO 389 MILES: LIVING THE BORDER POR LUIS CARLOS DAVIS
}

\begin{abstract}
Resumo: A utilização de múltiplas línguas nos filmes envolve frequentemente a estereotipagem negativa de personagens pertencentes à uma minoria representada nesses filmes. É o caso de alguns filmes de Hollywood em que o espanhol está associado a personagens exóticos ou perigosos, confirmando de forma persistente a posição dominante da língua inglesa. No documentário 389 Miles: Living the Border (2009), o impacto linguístico e cultural da migração é visto de uma perspectiva bastante diferente. Enquanto a maioria dos documentários sobre a fronteira méxico-americana é predominantemente em inglês, possivelmente com legendas em espanhol, ou principalmente em espanhol com legendas em inglês, em 389 Miles ambas as línguas são utilizadas de forma igual. O narrador conta a história em inglês, mas utiliza ambas as línguas nas entrevistas. Há também alguns personagens que mudam do inglês para o espanhol. O objetivo deste artigo é triplo: numa primeira instância, procura examinar o documentário com o uso de alguns conceitos básicos da Teoria dos Polissistemas. O segundo objetivo é explorar a diversidade linguística. Numa terceira instância, este artigo pretende lançar mais luz sobre dois poderosos símbolos mexicanos: a Virgem de Guadalupe e a máscara do lutador. O objetivo final é descobrir como o bilinguismo nos documentários muda a nossa percepção sobre outras culturas, a travessia de fronteiras e a migração.
\end{abstract}

Palavras-chave: Multilinguismo; Teoria dos Polissistemas; Documentário; Transferência cultural

\section{Introduction ${ }^{1}$}

Bilingualism in movies often reinforces stereotypes, as is the case with some American films in which Spanish is associated with exotic or dangerous characters, confirming persistently the dominant position of the English language. In the award-winning documentary 389 Miles: Living the Border (2009) by Luis Carlos Davis, the

\footnotetext{
${ }^{1}$ I would like to thank Guillermo Sanz Gallego for his insightful comments on an earlier version of this article.
}

Cad. Trad., Florianópolis, v. 40, ${ }^{0}$ esp., p. 113-132, jan./jul. sem. 1. 2020.114 
linguistic and cultural impact of migration is seen from a different perspective. ${ }^{2}$ The title refers to the length of the border between Arizona in the U.S. and the state of Sonora, in Mexico: from Mile 1 in Douglas, Arizona, to Mile 389, in San Luis, Sonora, Mexico. Davis was born in Nogales, Sonora, and at the age of nine moved with his family to Nogales, Arizona. A common name for the two border towns is Ambos Nogales, and its current history dates back to the first expeditions at the end of the $18^{\text {th }}$ Century. Davis does not want to show the border as a black and white story, but as a complex reality ( $q t d$ in Neyoy), and his view on the border is influenced by his own life story; he is the product of two cultures and two languages. From the very beginning, he presents the documentary as his personal story, in the first person, as a result of which he becomes involved in the development of the narrative:

I'm Luis Carlos Davis. [...] The border went through my town, my life and my soul. This documentary will take you on a human journey through that world, 389 miles of metal fence, border towns, open desert and the no man's land of Arizona and Sonora, where two countries collide. $(1: 08-1: 34)$

This young documentary maker addresses tough and controversial themes, such as survival, rape, human trafficking and corruption, and brings them out into the open to challenge the audience. In this documentary, characterized by autobiographical discourse and selfreflexivity, we recognize many features taken from what Hamid Naficy has called "accented cinema", i.e. films about marginalized

\footnotetext{
${ }^{2}$ There is already a large number of documentaries on the topic of migration along the border between Mexico and the U.S., and especially over the last ten years, this number has increased significantly. Examples worth mentioning are: Which Way Home by Rebecca Cammisa (2009); The 800 Mile Wall by John Carlos Frey (2009); 2501 Migrants: A Journey by Yolanda Cruz (2010); Purgatorio: A Journey Into the Heart of the Border by Rodrigo Reyes (2013).
} 
people and communities of immigrants in which the filmmaker tries to "counter negative or inaccurate stereotypes" (Naficy 65).

Whereas most of the documentaries dealing with the MexicanAmerican border are predominantly in English, possibly with Spanish subtitles, or mainly in Spanish with English subtitles, in 389 Miles both languages are used equally. The narrator Davis tells the story in English, but he uses both languages in the interviews with the people he meets along the border: some interviews are in English with Spanish subtitles and some are in Spanish with English subtitles. There are also a few characters who switch from English to Spanish.

The aim of this article is threefold: in a first instance, it aims to examine the documentary with the use of some basic concepts of Polysystem Theory (Even-Zohar). After this overall view we will then zoom in on the above-mentioned language diversity (Mamula and Patti) and find out how bilingualism in documentaries changes our perception of other cultures and of border crossings and migration (Deveny). On his journey, Davis meets many different people: migrants, missionaries, a coyote, the Border Patrol, minutemen, border residents, a schoolteacher, etc. These characters will be analyzed in terms of their language usage in the second part of this article. Special attention will be paid to the role of the interpreters on screen. Finally, in a third instance, this article aims to shed more light on two powerful Mexican symbols that appear in Spanish extracts: viz. the religious symbol of the Virgin of Guadalupe, and the cultural symbol of the wrestler mask. Both symbols are exemplar of cultural transfer between Mexico and the U.S.

\section{The Borderlands from the perspective of Polysystem Theory}

Polysystem Theory, as conceptualized by Even-Zohar, has been "designed to deal with specific problems in translation theory" (Codde 92), but also within literary studies it has proven to be 
an appropriate method for analyzing literary systems. According to Codde, Polysystem Theory at a certain point seemed to have lost some of its appeal for students and researchers of comparative literature, but there is no doubt that it still offers a "framework for a wide-ranging and still topical study of a variety of cultural phenomena" (Codde 91). From its inception, this model was designed to deal with the complexity of socio-cultural systems in a broader context. If we consider the borderlands as a cultural system, the concepts of Polysystem Theory help to understand the complex Mexican-American border as a multiple, dynamic and heterogeneous polysystem. The word "borderlands" is more appropriate here than "border" as Davis is not exactly following the border as a strict line; he is constantly crossing the border from one side to another. In the following analysis, five dichotomic pairs from Polysystem Theory are selected: viz. center and periphery, static and dynamic, homogeneous and heterogeneous, high culture and subculture, and intra and interrelations (Even-Zohar). By taking these five approaches as a methodological frame, we can ask specific questions. These pairs are not always in strict opposition; they can be present simultaneously, overlap and/or interact. This confirms the view of the Polysystem as an open structure with multiple and interdependent systems.

The most evident way of interpreting the first pair, i.e. center and periphery, is by applying it to the relation between the U.S., still the dominant center, and Mexico, a peripheral country. In fact, the whole Latin American continent has always suffered from being viewed as a peripheral region in the world and as a "forgotten continent" (Reid). But the documentary 389 Miles points out another context where the opposition between center and periphery is problematic. Davis wanted to interview people from the indigenous Tohono O'odham nation, who are divided on the issue of immigration. He went to the reservation, but could only talk to a few people off camera. Just recently someone was killed because he probably reported a coyote to the authorities. These people live in fear. In the hierarchy of central and peripheral cultures, this 
indigenous group is even more ignored and discriminated against. Their testimonies are kept in complete silence. We cannot even hear their voices; moreover, they have their own language, viz. Uto-Aztecan. To make matters even more complicated, their community lives on both sides of the border.

If we look into the second dichotomic pair, viz. static and dynamic, from the perspective of recent tendencies within Border Studies, the borderlands are usually perceived as a dynamic space with constant movements. In this documentary, however there is an interesting opposition. On the one hand, for Davis himself, the border is actually a static place: it is his home, his residence, his "soul": "The border is my stage, my backyard" (qtd in RuizMcGill). On the other hand, for the migrants, this border is a dynamic place as they do not stay or settle there but are just passing. The dynamic character of the borderlands not only has to be seen in space, but also in time. Many of these migrants have gone through traumatic events, which make them sometimes change their view on the border. There can even be ambivalence in one and the same person: the coyote is at the same time a bad guy and a good guy.

Thirdly, the borderlands in 389 Miles are seen as a heterogeneous space where people from all origins, races, social classes (high and low), etc. are interviewed. One of the fundamental ideas of Even-Zohar on the perception of the processes taking place in a heterogeneous system, is the "rejection of value judgments" in an "a priori selection of the objects of study" (Even-Zohar 292). At first sight Davis did not select his characters; he just interviews everyone he meets on his journey, in an arbitrary order. But it is clear that he made some decisions beforehand to show a very diverse view, with as many different characters as possible. Davis starts with some short questions and just lets them talk. His comments before or after the interviews are made to connect the dialogues, and we do not hear any value judgements.

As to the fourth opposition, viz. high versus low culture, Davis made a conscious decision: "I have no academics or scholars in this documentary" as his main objective was to "give voice to ordinary 
people" (qtd in Neyoy). Not only does he interview ordinary people such as farmers and migrants, he also goes further, and interviews a coyote: "I feel that I got into an underworld. I went to places that people do not normally watch" (qtd in Neyoy). Although we do not have information on the profession of the border resident called Manuel (20:18-22:14) it is clear that he belongs to a higher class, based on his solid analysis of the migration problem and on the style of the interview, which would perfectly fit in an academic setting.

Finally, also the tensions between intra and interrelations are very much present in the documentary. The interrelations can be seen at the level Mexico-U.S., as Davis explains in an interview about his documentary: "The border reality is that there is a dual economy. Both sides of the border depend on each other, and right now, both sides are hurting. They are connected. They've always been connected. Each Nogales is dependent on one another. That's something the border can't separate." (qtd in Herreras) But equally important are the intra-relations between people belonging to the same community: Mexicans among each other, and Americans among each other. The Mexican salesman talks about his clients from all over the world, but quite surprisingly, he says that the worst customers are the "Chicanos" from the U.S. When they cross the border to shop in Mexico, they treat the Mexicans very badly: "Estos nos tratan muy malo. Nos quieren humillar con cinco dólares. Esos son los racistas. Nuestra misma gente que nos quiere chingar. Discriminar. Con ellos sí me siento discriminado. Te miran así. Mira: 'Ay, this Mexican'” (31:36-33:43). Similarly, within the North American community the Border Patrol agent also expresses his scepticism about the minutemen.

On the whole, the above reflections in the light of Polysystem Theory make it possible to discuss multilingualism in the broader context of the borderlands. Especially in the first dichotomy, the tension between central and peripheral cultures runs parallel with language issues: Nahuatl and Uto-Aztecan appear as the most peripheral languages. As to the third dichotomy, we distinguish between homogeneous groups of Spanish-speaking immigrants 
and English-speaking minutemen, but mostly we are shown a heterogeneous view due to the mix of languages. In what follows, we will zoom in on this language diversity.

\section{The different characters}

\subsection{Extracts with only English-speaking characters}

We meet some members of the minutemen, but Davis is especially interested in interviewing Chris Simcox, the president of the Minuteman Civil Defense Corps (11:43-16:36). This Corps was founded in the early 2000 s as a vigilante organization to prevent illegal immigration, but its practices of reporting illegal immigrants have been controversial. The Minuteman Civil Defense Corps was dissolved in 2010. Simcox started as a minuteman after September 11. He calls migration an "invasion" and considers it "a terrible problem". He sees most of the immigrants as "criminals" and "terrorists". Simcox" language is also characterized by the use of exaggerations:

We have sent how many hundreds of our factories down to Mexico for the last ten years under NAFTA (North American Free Trade Agreement), but yet people continue to come to the north by the millions. [...] Our prisons are full of illegal immigrants who committed crime.

He is "optimistic" and thinks immigration will stop, although he supposes that "they probably are going to have to fill a couple of five or ten thousand more body bags." His language is aggressive and clearly inspired by right-wing extremism. 


\subsection{Extracts with only Spanish-speaking characters}

The main group is, of course, that of the migrants. In Sonoyta, Sonora, Davis interviews two deported migrants: a woman called Olivia and a man who remains anonymous (45:33-50:19). Olivia is crying incessantly during the entire interview. She attributes the fact that she was able to walk continuously for five to six hours to the drugs put into her soda by the coyote. The only thing she is relatively happy about is that she was neither robbed nor raped. But the worst thing is that she cannot find her husband. The separation of families is common among migrants and leads to dramatic situations. The man in that same interview had serious stomach pains, which can also be due to drugs they gave him. When his backpack started to tear apart, he asked the other migrants if he could put some of his stuff in their backpacks but they said "no". For him, crossing the border is a "catastrophic" and "tragic" experience, as everyone only cares about themselves. Both deported migrants speak freely in their mother tongue as if the documentary maker creates the space to let them speak with confidence. So exclusive use of Spanish renders despair and the traumas of migration.

Davis was also able to interview a coyote, a human smuggler called Chuy, in a house less than a mile from the fence (38:0843:10). Chuy speaks Spanish, which is clearly his mother tongue, but explicitly states that he has U.S. citizenship. He explains in the interview how he became a coyote and how he has been confronted with corruption on both sides of the border. People smugglers can make more than $\$ 200,000$ a year. He remembers that, as a kid, while he was playing next to the border fence, he saw a pregnant woman jump from the top of the fence. As her husband missed catching her, she lost her unborn child. That image kept haunting him and made him decide never to smuggle children into the United States. He knows his job is illegal, but he is convinced that he helps people who are poor and desperate to cross the border.

The next group of people who only speak Spanish are the residents on the Mexican side of the border (17:43-18:24). Davis

Cad. Trad., Florianópolis, v. 40, ${ }^{0}$ esp., p. 113-132, jan./jul. sem. 1. 2020. 121 
talks to them, mostly elderly people, while they are sitting on a bench. They feel that migration has changed their town "for the worse" as it has been "invaded" by drug and human traffickers:

Table 1: Residents on the Mexican side of the border

\begin{tabular}{|l|l|}
\hline Original voices & Subtitles \\
\hline $\begin{array}{l}\text { - Lo peor es la invasión de } \\
\text { gente del sur. }\end{array}$ & $\begin{array}{l}\text { - The worst is the invasion of people } \\
\text { from the south }\end{array}$ \\
\hline - La invasión. La invasión de & - The invasion. The invasion of the \\
chinos & Chinese. \\
- ... y mojados. & $-\ldots$ and wetbacks \\
- Toda la guachaca que & - All the guachada (Southerners) \\
llega nomás aquí a robar, a & that has [sic] come here to steal and \\
desprestigiar aquí el pueblo. & disgrace the town. \\
\hline
\end{tabular}

Source: O Autor.

In Spanish, the word "guachaca" catches the eye. In the English subtitles the word is transcribed as "guachada" and translated as "Southerners". The Real Academia indicates it as colloquial language from Chile, with the meaning of "ordinario, de mala clase". It has a negative connotation and expresses the border residents' discriminatory view of the people from the South.

Davis also follows an officer from the Grupo Beta called Enrique (27:59-31:32). The Grupo Beta is an official service organized by the Mexican National Institute of Migration. According to Enrique, the migrants only want to go to the U.S. to earn money; there is no reason to say that the migrant is a "threat". He drives around and talks to migrants to make sure they are alright. He is worried about the tumbadores, i.e. assailants who rob the migrants' belongings.

Another interview is that with a man who is called Manuel and who is only defined as a "border resident". He has a well-developed and nuanced view on the border conflict and comes up with a concrete solution (20:18-22:14): he concludes that there should be 
a system of temporary visas, a kind of "manual labor packages" with time limits, which could be called "legal traffic of manual labor". Manuel builds up a clear, convincing and well-structured argumentation in Spanish and gives a human image of the migrant as someone who only has the desire to progress, and of the migrant children as vulnerable people who need special protection.

Finally, the case of the two young missionaries from the U.S. is special as they appear to be the only Americans who speak Spanish (5:32-6:22). In fact, only one of them is talking and he makes a great effort to speak well and to give the entire interview in Spanish. He observes how people arrive in Sonora from everywhere, which he calls "un poco loco", a bit crazy. Apart from a slight accent, his level of Spanish is very good. Both men will be in Sonora for two years to do missionary work.

\subsection{Mixed extracts: code-switching or alternation between English and Spanish}

The Border Patrol officers speak English in the interviews with the documentary maker and Spanish with the migrants (1:47-5:02). According to agent Quinn, the majority of the agents are Hispanics, and also his wife is from Mexico. For Quinn this is a good thing, as he finds it important that "there is a lot of understanding of the culture". He is not happy with the minutemen; there is nothing the Border Patrol can do about them legally, but the biggest concern with these groups is safety. The difference between the minutemen and the Border Patrol officers is that the latter are trained for what they do. As to the different aspects of this training, Quinn mentions explicitly: "We're trained at [sic] Spanish". From this conversation with agent Quinn the viewer obtains a more human and more nuanced image both of the Border Patrol agents and of the immigrants. Within the Border Patrol, bilingualism is seen as a positive skill.

The second group who switches between the two languages are the "curioseros", i.e. the street vendors on the Mexican side of the border selling crafts (31:36-33:43). Since September 11, 
2001, business in the border towns has been struggling on both sides. The salesmen are laughing and seem to have a good sense of humor. One of the salesmen clearly enjoys switching from English to Spanish: he uses English when he talks to the people passing by his shop, and Spanish with Davis, the interviewer. For all these salesmen, code-switching is completely natural.

Another interviewee is Mark, a schoolteacher, who was born in a Mexican family that came to the U.S. legally a long time ago. (36:09-38:01). Mark is a Republican and as such he thinks that Mexicans should follow the legal procedures to come to the U.S., even though he is aware of the fact that many Hispanics are Democrats and therefore will not agree with his ideas. He does not look at the immigrants as Mexicans or Hispanics; for him, the only distinction is that between legal and illegal immigration. Quite interestingly Mark divides his interview into two parts: the first part is in English, the second in Spanish. Whether this switching is spontaneous or planned is difficult to say, but as a result of switching languages, bilingualism appears as a natural phenomenon on screen. In neither part does he apply code-switching. Mark presents himself as a bilingual person, but it has to be said that he is more fluent in English than in Spanish, which is common among Hispanics in the U.S. who had their education in English and speak Spanish only at home.

In the alternation between English and Spanish, there is of course a fundamental role played by translators and interpreters and it is revealing to see how they are represented on screen, both in films and in documentaries. According to Cronin,

because the interpreters must be there in order to ensure that individuals or groups may communicate with each other, they become witnesses to any number of dramatic or key events. [...] the interpreter can function as a perfectly plausible narrative device not only to precipitate change but also to report on it. (Cronin 111) 
In the documentary 389 Miles, there are two extracts with interpreters on screen. First, in the scene with a Mexican farmer and a minuteman, the interpreter appears to be the documentary maker himself. He has no central physical position, and is visible for a few seconds only. Nonetheless, he plays a central role in the communication: Paul, the minuteman, is happy with Davis's presence as it enables him to communicate with José. Actually, he wants to thank José for the fencing he placed for the cattle and asks the documentary maker explicitly to translate that:

(9:46-10:18)

- José: Este estaba en el suelo. Yo lo estoy reparando. El problema mío es el ganado, que se me va.

- Luis Carlos: ¿La gente que cruza le afecta a usted?

- José: Pues, destrozan el alambrado. Tiran mucha basura.

El ganado come la basura y se muere el ganado a veces. Sí hay cierto problema.

- Paul: I left a barbed wire for them. Tell him he did a wonderful job.

- Luis Carlos: Ya sabe todo el trabajo que hizo con el cerco.

- Paul: Tell him I said God bless him.

- Luis Carlos: Que Dios lo bendiga, dice.

- José: Gracias, gracias.

- Luis Carlos: He says 'Thank you'.

- Paul: Good. Good fences make good neighbors.

The Mexican farmer and the minuteman do not speak the same language. Both live in their respective monolingual worlds and the presence of the interpreter makes them feel more at ease.

The documentary is also about multilingualism as a third language is spoken as well, viz. Nahuatl. When Davis tries to talk to some migrant children, he notices that not all of them speak Spanish, but only what he calls "their native dialects". ${ }^{3}$ We can

${ }^{3}$ It needs to be clarified here that in Mexico people refer to other languages (Nahuatl, Totonaco, etc.) as dialects, while Spanish is supposedly the only 
hear surprise in Davis's words when he says that they do not speak Spanish "even when they are Mexican citizens" (24:04). With the help of a translator, José, another migrant child, Davis is able to communicate with the Nahuatl kid:

(23:56-24:33)

- The boy who only speaks Nahuatl: [...]

- The boy-interpreter (in Spanish): Dice que por dinero quiere ir a Estados Unidos, que no tiene.

- The boy-interpreter (in Nahuatl) with the boy: [...]

- The boy-interpreter (in Spanish): Dice que casi no se gana, que cuando iba a trabajar gana treinta pesos un día.

The Nahuatl kid is very shy, whereas the kid who takes the role of the interpreter looks much more confident; he knows he is in charge of the good results of the conversation, whereas the interpreter is supposedly invisible. For the kids who do not speak Spanish, migration to the United States becomes even more complicated. Another thing we can conclude from this extract is that Davis gives voice to everyone he meets on his trip along the border, even those whose languages he does not speak. For the audience, who probably will not be familiar with Nahuatl, this dialogue can possibly create a certain feeling of estrangement or surprise.

\section{Two Mexican symbols: the Virgen of Guadalupe and the wrestler mask}

The image of the Virgen of Guadalupe appears twice in the documentary. We first see her in a protest march by the organization No More Deaths. In this demonstration, which is taking place

language. This is, of course, a political misuse of the linguistic concepts of language and dialect. Nahuatl is a language with many varieties.

Cad. Trad., Florianópolis, v. 40, n $^{0}$ esp., p. 113-132, jan./jul. sem. 1. 2020. 126 
simultaneously on both sides of the border, two people can be seen carrying a banner with her image (18:39). At the end of the documentary, a group of migrants arrested by the Border Patrol are sitting on the sidewalk and one of them shows an image of the Virgen of Guadalupe and says:

$(51: 32-51: 43)$

Table 2: Group of migrants

\begin{tabular}{|l|l|}
\hline Original Voice & Subtitles \\
\hline $\begin{array}{l}\text { Migrant: Es mi virgencita. } \\
\text { Luis Carlos: Okay, pensé que } \\
\text { tenías comida o algo así. }\end{array}$ & $\begin{array}{l}\text { - I have my little mother. } \\
\text { - Oh, I thought it was food or } \\
\text { something like that. }\end{array}$ \\
\hline $\begin{array}{l}\text { Migrant: Oh, no, qué pasó... } \\
\begin{array}{l}\text { Other migrant: Mejor que la } \\
\text { comida. }\end{array}\end{array}$ & - Oh, what's up with that. \\
\hline
\end{tabular}

Source: O Autor.

To understand the full meaning of both extracts, it is necessary to explain briefly the significance of the Virgin of Guadalupe, who is omnipresent in popular culture. She is much more than a religious image and became a symbol of Mexican national identity, uniting believers and non-believers. She appears in art works by great artists and in kitsch art. There is, for instance, a photo dating from 1989 by Mexican photographer Graciela Iturbide which is entitled $L a$ frontera (Fundación Mapfre 185) and which represents a man with a tattoo of the Virgin. The Virgin appears as a protector of people who attempt the border crossing. The migrants wear her image on a drawing, as can be seen in the documentary, but also on medals, t-shirts, devotional pictures, and tattoos. It seems that in those extreme situations their faith keeps them going (Zambrano). When the migrant in the documentary shows his image of the Virgen, he looks happy for a moment, and that scene even ends with the whole group of migrants laughing. We also notice that the migrant kisses the image of the Virgin, in the hope that she will bring good luck. 
The second cultural symbol from Mexico is the wrestler mask. Chuy, the smuggler, agreed to participate in the documentary on two conditions, as Davis explains in the documentary:

[F]irst, only one companion and I would know about this interview and second, I would provide him with assurance that his face would be covered. He gave me very limited time to prepare for this interview. It was now or never. Fortunately, I remembered my brother's Blue Demon mask in my car and quickly procured it. (38:08-38:37)

Apart from the aesthetic significance of this extract there is also the symbolic power which comes from wearing a mask. To understand that, some fundamental aspects about the Lucha Libre in Mexico and especially about Blue Demon should be explained. Wrestling in Mexico is a popular sport which started in the 1930s. The fight is always between the Técnicos and the Rudos, the "good guys" and the "bad guys". Their expressive masks give them enhanced strength and their combat reaches mythical proportions. It is a symbolic, even sacred, fight between Good and Evil. The mask is not only an element of Mexican culture in pre-Hispanic religions, festivals and wrestling, it is also a basic concept of being Mexican. In The Labyrinth of Solitude, Octavio Paz refers to the mask in its figurative sense (Paz, 34). There is always a game of identity: it can mean hiding, splitting or reinforcing one's own identity. By wearing a mask, whether it is a wrestler or any other figure, the wearer not only hides or changes his/her identity, but also obtains special, supernatural or divine powers from it. This was especially the case of Blue Demon, a masked professional wrestler whose real name was Alejandro Muñoz Moreno (1922-2000). He was one of the so called "big three" of traditional wrestling in Mexico, the other two being El Santo and Mil Máscaras.

The use of the wrestler mask in the documentary was purely accidental. Nonetheless, the result is that for several minutes, the 
viewer sees a beautiful image of that Blue Demon mask and the close-ups even add artistic value to it. When Chuy, the smuggler, is talking, he sounds like a sympathetic and ordinary man, but that mask actually gives him the status of a hero with sacred powers. The smuggler is hiding his identity, but at the same time his identity is divided between the good and the bad. Inevitably, there is also a fascination with the mysterious character of the person behind the mask. Davis ends that extract with the following words: "When the interview ended, Chuy got up, said good-bye and left. To this day, I have never seen Chuy again or my brother's Blue Demon mask." (43:01-43:09)

\section{Conclusion}

The fact that the director of the documentary is the narrator of the story is an aspect that we usually associate with subjectivity. At the same time, the multiple interviews give a more objective perspective on the phenomenon of migration. Davis tells his own story, but seems distant or absent in some of the interviews. The documentary maker plays different roles throughout the documentary, which gives him a complex identity: he is an intradiegetic narrator, a character, an activist, an interpreter on screen, and even a cultural mediator, as we have seen with the two significant symbols of cultural transfer, viz. the Virgin of Guadalupe, and the wrestler mask. In fact, we could also see Davis as a cultural translator: he manages to highlight how languages play an important role in the construction of a specific narrative. English is therefore associated with authority, intolerance, punishment and disciplinary action. Spanish, on the other hand, is related to empathy, inclusion, affinity and fellowship. Indeed, some characters who communicate in English, such as the minuteman, perceive the immigrants as "criminals", whereas characters who communicate in Spanish, such as Enrique from Grupo Beta, see the immigrants as victims. But this division is, of course, too schematic as becomes clear 
in the song "Alejandro", which concludes the documentary. The song, written in English by Gary Mackender for his band the Carnivaleros, represents the Mexican migrants as victims dying in the desert, as expressed in the introduction of the song:
Alejandro don't you walk into the desert tonight
Begged his wife the night he wanted to go
The road is strewn with signs of those who tried before you
Maybe this time make it out of Mexico

Also the many extracts with code-switching reflect mixed views on the topic. The hypothesis at the beginning of this article was that in the interviews Spanish and English appear to be well balanced, but the fact that Davis chooses to narrate the story in English probably brings the whole documentary out of balance. The social impact of the documentary has been substantial, not only on the border communities, but also around the world, and the current topic of migration gives this documentary a "performative expression of deterritorialization" (Naficy 143). According to Davis, it was because of a conversation with his mother that he decided to make the entire documentary available on Youtube: "She said you can always do commercial film in the future, but 389 Miles does not belong to you anymore; it belongs to the world." (Davis) If this documentary now belongs to the world, paradoxically, English seems to be the dominant language to bring Davis's message to audiences all around the globe. 


\section{References}

Cammisa, Rebecca. Which Way Home. HBO Films, DVD 1h 30 m, 2009.

Codde, Philippe. "Polysystem Theory Revisited: A New Comparative Introduction". Poetics Today. 24-1, (2003): 91-126.

Cronin, Michael. Translation Goes to the Movies. London, New York: Routledge, 2009.

Cruz, Yolanda. 2501 Migrants: A Journey/Reencuentros. Petate Productions, DVD 57 min., 2010.

Davis, Luis Carlos. 389 Miles: Living the Border. Full Movie (2009). Avaible to:: www.389miles.com. Access in: 7 February 2020.

Deveny, Thomas. Migration in Contemporary Hispanic Cinema. Lanham/ Toronto/Plymouth: Scarecrow Press, 2012.

Even-Zohar, Itamar. "Polysystem Theory". Poetics Today. 1, 1-2, (1979): 287310.

Fundación Mapfre. Graciela Iturbide (catálogo), del 16 de junio al 6 de septiembre de 2009. Madrid: Fundación Mapfre, 2009.

Herreras, Mari. “T Q\&A”. Tucson Weekly. 14 May 2009. Avaible to: https:// www.tucsonweekly.com/tucson/t-qanda/Content?oid $=1184769$. Access in: 7 February 2020.

Mamula, Tijana; Patti, Lisa (Eds.). The Multilingual Screen: New Reflections on Cinema and Linguistic Difference. New York: Bloomsbury, 2016.

Naficy, Hamid. An Accented Cinema: Exilic and Diasporic Filmmaking. Princeton, NJ: Princeton University Press, 2001. 
Neyoy, Cesar. "Hispanic Face. The border from a clear lens". Bajo el Sol. 3 April 2010. Avaible to: http://myeveryday-fenceproductions.blogspot.com/2010/04/bajael-solenglish-and-spanish-version.html. Access in: 7 February 2020.

Paz, Octavio. El laberinto de la soledad. México: FCE, 1991.

Reid, Michael. Forgotten Continent. A History of the New Latin America. New Haven and London: Yale University Press, 2009.

Reyes, Rodrigo. Purgatorio: A Journey Into the Heart of the Border. DVD $1 \mathrm{~h}$ 21m., Foprocine, La Maroma Producciones, 2013.

Ruiz-McGill, Rebecca. "UA Filmmaking Student Captures Life in His Backyard: the Border". UA. News 8 March 2008. Avaible to: https://uanews.arizona.edu/ story/ua-filmmaking-student-captures-life-in-his-backyard-the-border. Access in: 7 February 2020.

Zambrano, Jaime. "Virgen de Guadalupe, acompañante de los migrantes". Milenio. 12 December 2017. Avaible to: https://www.milenio.com/opinion/ jaime-zambrano/desde-el-biopoder/virgen-de-guadalupe-acompanante-de-losmigrantes. Access in: 7 February 2020.

Recebido em: 26/02/2020

Aceito em: 23/04/2020

Publicado em julho de 2020

An Van Hecke. E-mail: an.vanhecke@kuleuven.be. ORCID: http://orcid. org/0000-0001-7025-7758

Cad. Trad., Florianópolis, v. 40, n $^{0}$ esp., p. 113-132, jan./jul. sem. 1. 2020. 132 